УДК 398.23

DOI https://doi.org/10.26661/2414-9594-2020-2-19

\title{
АВТОСТЕРЕОТИПНІ РИСИ ПОЛЯКА В АНЕКДОТАХ (НА МАТЕРІАЛІ АНКЕТУВАННЯ СТУДЕНТСЬКОЇ МОЛОДІ ПОЛЬЩІ)
}

\author{
Филипець О. 3. \\ аспірант кафедри польської філології \\ Львівський наџіональний університет імені Івана Франка \\ вул. Університетська, 1, Львів, Україна \\ orcid.org/0000-0002-4161-408X \\ dyka.olya@gmail.com
}

\author{
Ключові слова: \\ автостереотип поляка, \\ польська молодь, анкетування, \\ анекдот, мовна картина \\ cвimy.
}

У статті здійснено аналіз автостереотипних рис поляка на основі анекдотів, зібраних шляхом анонімного анкетування студентів із різних регіонів Польщі. Респондентами стало 1195 студентів-філологів польських вищих навчальних закладів: Університету імені Адама Міцкевича в Познані, Університету імені Марії Кюрі-Склодовської в Любліні, Університету Миколая Коперника в Торуні, Сілезького університету в Катовіцах, Ягеллонського університету в Кракові, Лодзького університету, Вроцлавського університету та Жешівського університету. Запропоноване дослідження передбачало зібрання відповідей на одне запитання анкети: Proszę napisać znane Pani/ Panu dowcipy o Polakach. Усі виявлені в запропонованих студентами анекдотах риси залічено до різних аспектів позамовної дійсності: комунікаційно-психічного, психосуспільного, культурного, фізичного та політичного. Простежено, що всі зібрані 3 анкет анекдоти про поляків є носіями негативних і позитивних автостереотипних рис. 3'ясовано, що в межах психосуспільного аспекту злодійство поляка домінуе над лінивством та алкоголізмом. У світлі комунікаційнопсихічного аспекту вміння давати собі раду чи знаходити вихід із кожної ситуації, відважність поляка домінують над жорстокістю та заздрістю. Крізь призму культурного аспекту в анекдотах часто експонується така автостереотипна риса, як відсталість. Фізичний аспект представлений однією автостереотипною рисою поляка брудний. Зібраний матеріал дав змогу простежити, що експоновані автостереотипні риси увиразнюються шляхом протиставлення поляка i представників інших національностей у різних конфігураціях. Героями анекдотів здебільшого є представники класичної тріади національностей: поляк, німець, «русек». Зрідка в запропонованих студентами анекдотах як третій представник національності виступає американець, француз чи японець. 


\title{
AUTOSTEREOTYPICAL FEATURES OF A POLE IN ANECDOTES (ON THE MATERIALS OF THE SURVEY OF STUDENT YOUTH IN POLAND)
}

\author{
Fylypets O. Z. \\ Postgraduate Student at the Department of Polish Philology \\ Ivan Franko National University of Lviv \\ University str., 1, Lviv, Ukraine \\ orcid.org/0000-0002-4161-408X \\ dyka.olya@gmail.com
}

Key words: autostereotype of a Pole, Polish youth, questionnaire, anecdote, language picture of the world.
The article analyzes the autostereotypical traits of a Pole on the basis of anecdotes collected by anonymous questionnaires of students from different regions of Poland. 1195 students of philology of Polish higher education institutions became the respondents: Adam Mickiewicz University in Poznań, Maria CurieSklodowska University in Lublin, Nicolaus Copernicus University in Torun, University of Silesia in Katowice, the Jagiellonian University in Kraków, the University of Wrocław, the University of Rzeszów and the University of Łódź. The proposed study provided for the collection of answers to one question of the questionnaire: Proszę napisać znane Pani / Panu dowcipy o Polakach / Please write jokes you know about Poles. All the features had found in the anecdotes suggested by the students are included in various aspects of extraverbal reality: communicative-mental, psycho-social, cultural, physical and political. It has been observed that all anecdotes about Poles collected from the questionnaires are carriers of negative and positive autostereotype traits. It has been found that in the psycho-social aspect, Polish theft dominates over laziness and alcoholism. In the light of the communication and mental aspect, the ability to cope with and find a way out of every situation, courage of a Pole dominate over cruelty and envy. The feature of backwardness is often exposed through the prism of the cultural aspect. The physical aspect is represented by one autostereotypical feature of the Pole - dirty. The collected material made it possible to trace that the exhibited autostereotypical features are expressed by contrasting the Pole and representatives of other nationalities in different configurations. The heroes of the anecdotes are mostly representatives of the classical triad of nationalities: Pole, German, "Rusek". Occasionally, in the anecdotes suggested by students, an American, a Frenchman, or a Japanese appear as the third representative of nationality.
Вступ. Згідно 3 науковим інструментарієм польської етнолінгвістики стереотип - це «суб' єктивно детерміноване, спрощене, узагальнене уявлення про певний об'єкт, що містить відповідну оцінку і є інтерпретацією реальності» [8, с. 24]. Найповніше стереотипні уявлення виявляються в розмовній мові - т.зв. поточному типі раціональності, що становить «центр системи стилів польської мови» [7, с. 283]. Вважається, що серед трьох типів даних (система мови, анкета, текст) саме шляхом анкетування можна дослідити поточну мовну свідомість мовців, розуміння ними слів [7, с. 287]. Анкетування дає змогу проаналізувати актуальний стан знань мовців про навколишній світ і ступінь стабілізації виокремлених стереотипних уявлень в окресленій групі респондентів. Шляхом анкетування можна дослідити, серед іншого, закріплені в мовній свідомості респондентів анекдоти. Анекдоти в розмовній мові, як уважає П. Каяк, руйнують повсякденні, колективні та політичні табу, спираються на стереотипи та їх поширюють. Такі стереотипи можна трактувати, як певні знання, що не завжди є негативними [15]. Як зауважують учені, «анекдоти - це стереотипогенний жанр, що $є$ носієм стереотипів, і в якому відбувається гостре відокремлення увиразнених, загострених чи іноді доведених до абсурду стереотипних рис» [9, с. 128]. Наприклад, анекдоти про національності відображають важливі для лінгвокультурної спільноти авто- (про себе) і гетеростереотипні (про людей 3-поза спільноти) риси. На прикладі праці про стереотип росіянина в сучасній польській мові доведено, що анекдоти про національності вважаються дуже придатним і 
вдячним матеріалом для дослідженнях стереотипів [9, с. 128]. Д. Буттлер розрізняє три значення терміна «анекдот» (пол. dowcip): «1) усі засоби, що здатні передати комічну інтенцію творця; 2) усі форми свідомої мовної творчості жартівливого характеру; 3) чітко визначена, коротка текстова структура 3 постійною композицією, що завершується несподіваною кінцівкою» [13, с. 30]. Останнє визначення слова анекдот також відповідає дефініції цього терміна в «Словнику понять i текстів культури» (пор.: «короткий наративний текст із непередбачуваним завершенням (висновком), що має на меті розвеселити адресанта» [22, с. 309]. Важливим є також факт, що цей словник уміщує значення слова анекдот (пол. dowcip) серед текстів культури [22, с. 309]. Однак міжмовна еквівалентність термінів «dowcip» та «анекдот» не $\epsilon$ абсолютною. Польський термін «dowcip» уживається в ширшому значенні, ніж український відповідник «анекдот», адже охоплює, окрім «смішної історії (оповідання)», ще й «короткий вислів, що викликає сміх» [20]. Його український відповідник «анекдот» уживають на позначення «короткого жартівливого (здебільшого вигаданого) оповідання про яку-небудь смішну подію» [2]. Підтверджує цю тезу низка українських фольклористичних досліджень анекдотів, якими є короткі гумористичні чи сатиричні оповідання різного змісту [див. 1]. У запропонованій статті анекдотом уважаємо всі

\footnotetext{
${ }^{1}$ Термін «аспект» уживаємо вслід за вченими-етнолінгвістами в значенні «домени, виокремлені 3 визначеної точки зору» $[18$, с. 78$]$. Під час опису предмета суб'єкт бере до уваги певний напрям його розгляду, бік його інтерпретації. Таке значення терміна «аспект» накладається на поняття «перспективи», яке в категорійному апараті етнолінгвістики визначають як «сукупність властивостей семантичної структури слів». Учені наголошують, що тут ідеться «про сукупність аспектів (сторін) предмета (об'єкта), які мовці беруть до уваги в невипадковому порядку. Ці аспекти укладаються в певні конфігурації і творять своєрідний профіль поняття» [10, с. 112]. У польських етнолінгвістичних дослідженнях уживають термін «фасет» як взаємозамінний до «аспекту». Однак недоцільно ототожнювати ці терміни, адже «фасет» означає «підкатегорію» чи «групу класів, що відповідають якійсь спільній характеристиці» [18, с. 78]. Набір фасетів є сталим, а набір аспектів зумовлений зібраним матеріалом.

${ }^{2}$ Д. Бжозовська стверджує, що такий уклад персонажів анекдотів про національності сформувався історично: під час Другої світової війни поляки контактували з німцями, а комуністичний період призвів до частих контактів із росіянами. Однак один із традиційних героїв анекдотів - «русек» не завжди є росіянином, адже «русеком» поляки називають також «усіх мешканців колишнього СРСР, незважаючи на національність» [23]. В одному зі словників польської мови при визначенні «русека» як «особи, що походить із теритоpiї колишнього СРСР» [6, с. 521] міститься кваліфікатор, що це «слово $є$ поточним і виражає презирство та зневагу» $[6$, c. 521]. Інколи в анекдотах про національності фігурують також євреї чи американці [12, с. 600-601].

${ }^{3}$ Усі студентські відповіді подаємо в оригіналі.

${ }^{4}$ Цифра в дужках означає кількість однакових відповідей респондентів або актуалізацію в анекдотах аналізованої автостереотипної риси у відсотках.

${ }^{5}$ Перелік скорочень уміщено під текстом статті.
}

форми мовної творчості студентів жартівливого характеру: короткі оповідання і вислови. Вважаємо, що анекдоти є носіями стереотипних рис крізь призму окремих аспектів ${ }^{1}$.

Аналіз останніх досліджень і публікацій. Дослідженню автостереотипу поляка шляхом анкетування в польському і українському мовознавстві присвячено низку праць $[11 ; 21 ; 3 ; 4 ; 5]$. Відомі також дослідження, у яких учені аналізували мовно-культурні образи об'єктів (зокрема, національностей) на матеріалі виокремлених 3 анкет анекдотів [9; 17; 16; 14]. Доцільність використання анекдотів про національності (зокрема, про поляка) на заняттях 3 польської культури як іноземної обгрунтував П. Каяк [15]. Про стереотип науковця на матеріалі польських анекдотів писала Д. Бжозовська [12]. У польському й українському мовознавстві бракує, однак, поглиблених анкетних досліджень автостереотипу поляка, що актуалізується в польських анекдотах, які побутують у мовній свідомості польських студентів із різних регіонів Польщі.

Мета дослідження - виявити автостереотипні риси поляка на матеріалі анекдотів, закріплених у мовній свідомості студентської молоді Польщі.

Матеріальну базу дослідження становлять 96 одиниць, серед яких і класичні за жанром «анекдоти», і мовні жарти довільної форми, зібрані шляхом проведення впродовж 2018-2019 років анонімного анкетування серед студентів університетів із різних регіонів Польщі. Респондентами стали 1195 студентів-філологів: Університету ім. Адама Міцкевича в Познані (140 студентів), Ягеллонського університету (117 студентів), Жешівського університету (197 студентів), Університету ім. Марії Кюрі-Склодовської в Любліні (110 студентів), Університету Миколая Коперника в Торуні (166 студентів), Вроцлавського університету (140 студентів), Сілезького університету (128 студентів) та Лодзького університету (197 студентів). Кожна група студентів налічує понад 100 респондентів. Це свідчить про репрезентативність даних у кожному студентському середовищі [7]. На потреби цього дослідження аналізу піддаємо відповіді на одне запитання анкети: Prosze napisać znane Pani/Panu dowcipy o Polakach. Слід зазначити, що на це запитання відповіло лише 365 (30,5\%) респондентів. Не відповіло - 830 (69,5\%) анкетованих. Звідси можемо припустити, що респонденти не знають анекдотів про поляків.

Аналіз матеріалу. Відповідаючи на анкетне запитання, респонденти найчастіше лише вказують на тип анекдотів (без подальшого прикладу тексту), в яких героями виступає відома тріада національностей «поляк, німець, «русек» ${ }^{2}$ «Z cyklu «byt sobie Niemiec, Rusek, Polak» (784) $\left(B^{5}, \mathcal{K}, T\right.$, Лб, П, $\left.K, K p, Л\right)$. Як бачимо, часта згадка 
про такий цикл анекдотів відображає канон польських анекдотів про національності, представниками яких $\epsilon$ найближчі сусіди поляків. Студенти при цьому зрідка додають, які основні автостереотипні риси актуалізуються в таких анекдотах: wszystkie dowcipy typu Niemiec, Polak, Rusek, które pokazuja spryt, pazerność i prostote myślenia Polaka (5) (B); jest wiele dowcipów o Polakach w kręgu dowcipów o początku "Polak, Niemiec i Rusek», gdzie Polak jest zawsze najbardziej ekstremalny (B); o Polaku, Rusku, Niemcu, gdzie Polak potrafi wypic najwięcej $i$ nic mu nie jest $(K)$. На думку респондентів, у таких анекдотах поляк уміє давати собі раду, екстремальний, жадібний, любить алкоголь, що характеризує його простий спосіб мислення.

Окрім згадки про популярну серію анекдотів із традиційними героями, студенти наводять низку прикладів текстів, у яких зображені автостереотипні риси поляка. Усі експоновані риси ми залічуємо до різних аспектів: комунікаційно-психічного, культурного, психосуспільного, фізичного та політичного.

Велику групу становлять анекдоти, у яких експліцитно відображається автостереотип поляка-злодія (30,2\%), що пов'язується із психосуспільним аспектом.

1. «Co jest dobrego w mroźnej pogodzie? - To, że Polacy trzymają ręce we własnych kieszeniach» (T).

2. «Dwóch kanibali smażyjedzenie nad ogniskiem. Jeden kanibal mówi do drugiego: - Trzymaj wyżej to mięso, to Polak, jeszcze ukradnie nam węgiel» $(\mathrm{K})$.

3. «Co by się stało, gdyby Polaka przenieść na Saharę? - Przez pierwsze 7 lat nic, a potem zaczęłoby brakować piasku» (2) (Ж).

У двох анекдотах, запропонованих респондентами 3 Катовіц і Жешова, головними героями виступають традиційні представники трьох національностей - німець, поляк, «русек», серед яких поляк учиняє крадіжку: "Pociagiem jedzie Polak, Niemiec i Rusek. Zakładaja się, że przy zgaszonym na 10 sekund świetle uda im się ukraść wspótpodróżnym paski od spodni. Gdy nadeszła kolej Polaka, po właczonym ponownie świetle nastapił komunikat, że musza przerwać podróż, bo ukradziono lokomotywę» (K) й т. ін. ${ }^{6}$

Пейоративна риса «злодійство», що відсилає до психосуспільного аспекту, в деяких запропонованих респондентами анекдотах виявляється імпліцитно, наприклад:

\footnotetext{
6 "Komendant policji pojmat trzech więźniów, każdemu z nich $w$ zamian za wyjście wolno polecit $w$ czasie minuty rozbroić sejf Pierwszy do zadania przystapił Rosjanin, po uptywie czasu dźwięków uderzania o sejf różnymi narzędziami, wyszedł z celi ze smutna mina sygnalizująca niepowodzenie. Niemiec postanowit wziać dynamitu, jednak po wybuchu nic sie nie stało. Przyszła kolej na Polaka, wszedt do celi. Po uptywie minuty $w$ dalszym ciagu nic nie stychać. Komendant otwiera cele i próbuje włączyc światto. Nie udaje się. Katem oka widzi Polaka, który w reku trzyma zarówno gotówkę z sejfu, jak i wykręcona żarówkę” (Ж).
}

1. «Dlaczego nie powinieneś potracać Polaka jadacego na rowerze? Możliwe, że to twój rower (9) $(\Pi, K, \mathcal{K}, T, K p) »$;

2. «Jak jesteś w Polsce, to uważaj, żebyś nie potracit roweru. - Dlaczego? - Bo to może być twój rower» (Л);

3. «Jak nazywać Polaka bez rake? - Godny zaufania (2)» (Ж, T).

Автостереотипна риса «злодійство» віддзеркалюється також в анекдотах, головними героями яких $є$ поляк та німець. У них фігурує також образ Польщі. Важливим компонентом такого типу анекдотів є крадіжка поляком транспортного засобу, наприклад, велосипеда чи автомобіля. Польські студенти вказують, що представлені ними анекдоти побутують серед німців. Наприклад, 7 разів у анкетних відповідях натрапляємо на анекдот типу: «Jedź do Polski. Twój samochód już tam jest» (6) (niemiecki dowcip) (П, В, Ж, Л) або "Witamy w Polsce, twój samochód juz tu jest!» (Niemcy o Polakach) (B).

Серед анкетних відповідей жешівських студентів виокремлюємо такі два анекдоти:

1. "Niemiecki dowcip o Polakach. Was ist BMW fur Polen - czym jest BMW dla Polaka? - Bpld Mein Wagen - Wkrótce moje auto» (Ж).

2. «Kto pierwszy wynalazt rower? - Polak u Niemca na strychu» (Ж).

Слід зауважити, що географічне розташування польських міст відповідно до кордону з Німеччиною не вплинуло на поширення анекдотів 3 персонажами поляка і німця у мовній свідомості респондентів, адже знаходимо такого типу анекдоти не лише серед студентів із Познані, Вроцлава, Лодзі, але й Жешова.

Наступна група анекдотів репрезентує алкоголізм $(8,33 \%)$ поляків. Цю рису залічуємо до психосуспільного аспекту. Будова сюжету $є$ традиційною, де представлені три національності: поляк, німець, «русек»/американець. Здебільшого поляк як головний герой анекдотів виступає переможцем у змаганнях, хто вип'є більше алкоголю. Наприклад, «Zawody w piciu wódki. Amerykanin, Rusek, Polak pija wódkę, kieliszek po kieliszku. Amerykanin odpada. Zostaje Polak i Rusek. Ida teb w teb. Rusek powoli wymięka. Nagle Polak woła: «Stop, stop. Sorry, muszę kończyć, bo umówiłem się na picie» (2) (Ж).

На два схожі сюжети анекдоту, що реалізує автостереотипну рису «алкоголізм», натрапляємо в жешівському і лодзькому середовищі. Кінцівка такого сюжету, окрім висвітлення любові до алкоголю, представляє також уміння поляків знаходити вихід із кожної ситуації:

1. «Wchodzi do polskiego baru obcokrajowiec. Siada i mówi: - Dam 20 funtów temu, kto na raz wypije pół litra wódki, $W$ barze nastała cisza, nikt 
nie ma odwagi się zglosić, tylko jeden mężczyzna wychodzi chytkiem z baru. Po 15 minutach wraca $i$ mówi: - Zrobie to. Obcokrajowiec kupuje wódke, Polak ja szybko wypija, bierze nagrodę od obcokrajowca. Obcokrajowiec jednak pyta. Czemu wyszedteś z baru wcześniej? Polak odpowiada: Poszedtem do baru obok sprawdzić, czy mi się uda» (K);

2. «Polak założyt sie z kimś, że wypije za raz cała butelkę wódki. Umówit się w pewnym barze o określonej porze, ale Polak się spóźnia. W końcu przychodzi i mówi. - Przepraszam, że spóźnitem się, ale byłem $w$ barze obok, żeby sprawdzić, czy dam radę» (Л).

Один із респондентів наводить приклад модифікації вірша Владислава Белзи «Катехизм польської дитини», у якому також експонується алкоголізм поляків:

$$
\begin{aligned}
& \text { "- Kto ty jesteś? } \\
& \text { - Polak maty. } \\
& \text { - Jaki znak twój? } \\
& \text { - Trzy browary. } \\
& \text { - Gdzie ty mieszkasz? } \\
& \text { - Pod taweczka. } \\
& \text { - Czym się bronisz? } \\
& \text { - Buteleczką» (Ж). }
\end{aligned}
$$

В одному з наведених нижче анекдотів спостерігаємо форми прояву чорного гумору із віддзеркаленням алкоголізму поляків: «Jaka jest różnica między polskim ślubem a pogrzebem? - Na pogrzebie jest o jednego pijanego mniej» (Ж).

Наступний анекдот зображує представників трьох національностей 3 урахуванням лексичних особливостей мовлення, а отже - у світлі культурного аспекту. Слід додати, що автостереотипний образ поляка в цьому анекдоті містить рису «любов до алкоголю», а отже, стосується також психосуспільного аспекту. Текст анекдоту відображає, що в ментальному лексиконі поляків поширене слово горілка, німців - Слава Гітлеру!, росіян - здравствуйте. 3 цими мовними маркерами польські студенти асоціюють німців та росіян. Наприклад, "Ida Polak, Rusek, Niemiec przez las i nagle zatrzymat ich diabet. Jeśli powiecie coś i przez 20 min. będzie stychać echo, to was puszczę. Pierwszy byt Niemiec: - Hej, Hitler! Gtos rozchodzi sie 5 min. Nastepny byt Rusek: Zdrastwujcie! Gtos rozchodzit się $10 \mathrm{~min}$. Ostatni byt Polak: - Wódka. - Gdzie? Rozchodziło sie 2 godziny» (Ж).

\footnotetext{
7 Як бачимо, японець виступає лише в одному гумористичному тексті. Виявлено ще один текст, де віддзеркалено стереотипи Японії та Польщі: “Czym różni sie Japonia od Polski? Bo Japonia to kwiat kwitnacej wiśni. A Polska to kwiat kwitnacej lipy” (T). Слід додати, що слово lipa респонденти вживають у непрямому значенні як «брехня, шахрайство». Про проблему значення слів lipa/липа, lipny/липовий у польській і російській мовах писав М. Скаржинський [див. 19, с. 195-204].
}

Закріплені в мовній свідомості студентів анекдоти увиразнюють автостереотипні риси «відважність» $(8,3 \%)$ і «вміння давати собі раду чи знаходити вихід із кожної ситуації» $(13,5 \%)$. Ці риси реалізують критерій комунікаційних здібностей i залежать від моральних якостей людини, а отже, стосуються комунікаційно-психічного аспекту позамовної дійсності. Однакові сюжети з'являються в текстах анекдотів, запропонованих, наприклад, респондентами з Познані, Вроцлава, Торуня, Кракова: «W balonie podróżuja Polak, Francuz i Niemiec. Przewoźnik mówi Francuzowi, ze teraz jest moda na wyskakiwanie $z$ balonu. Francuz wyskoczyt. Następnie przewoźnik mówi, ze teraz wyskakuje się z balonu ku chwale ojczyzny i przodków. Niemiec wyskoczyt. Później przewoźnik próbuje przekonać Polaka, ale mu się nie udaje. $W$ końcu mówi do niego: - Nie wyskoczysz. Na co Polak: - Ja nie wyskoczę? I wyskoczyt» (4) (B, T, Kp).

Відважний поляк, який не боїться духів, зображений у такому анекдоті: «Polak, Niemiec i Rusek chcieli zostać na noc $w$ pewnym hotelu. Obstuga poinformowata ich, że straszy tu duch "Zielone oczko». - To nic, my się nie boimy. Jest pótnoc. Do pokoju Niemca przychodzi duch: - Jestem duch "Zielone oczko». Niemiec się przestraszyt $i$ uciekt. Tak samo byto z Ruskiem. Przychodzi duch do pokoju Polaka i mówi: - Jestem duch "Zielone oczko». Polak na to: - Jak ci zaraz przywale, to będziesz miat fioletowe» (Ж).

У низці анекдотів експонується автостереотип поляка як лінивої $(10,41 \%)$ людини. Цю виявлену рису вміщуємо в межах психосуспільного аспекту. Наводимо нижче тексти анекдоту, де одночасно виявляються автостереотипні й гетеростереотипні уявлення польських студентів. Можна припустити, що в першому прикладі характерною рисою польки є лінощі, а росіянина - злодійство: "Co urodzi się ze zwiazku Polki z Rosjaninem? Dziecko zbyt leniwe, żeby kraść (9) (B, Ж, T)».

Натомість у другом прикладі актуалізується гетеростереотипна модель японця як працьовитого, а полякові приписується автостереотипна риса «лінивий»: «Co robi Japończyk ${ }^{7}$, by otrzymać podwyżkę? - Pracuje jeszcze lepiej. - Co robi Polak, by otrzymać podwyżę? - Strajkuje» (Ж).

У чотирьох студентських середовищах Познань, Лодзь, Катовіце, Жешів - побутує анекдот, крізь призму якого відображаються лінивство і відсталість (13,5\%) поляків: «Do wkręcania żarówek potrzeba trzech Polaków - 2 do trzymania drabiny $i$ jednego do trzymania żarówki» (4) $(П, Л, K, Ж)$. Експоновані риси в цьому анекдоті можуть бути складниками психосуспільного і культурного аспекту.

Автостереотипний образ поляка в анекдотах характеризується рисою «заздрість» $(3,1 \%)$, що 
пов'язує сприйняття поляка крізь призму комунікаційно-психічного аспекту. Сюжет анекдотів, що засвідчують таку рису, розгортається навколо трьох національностей у різних конфігураціях. Здебільшого заздрість поляка проявляється щодо сусіда:

1. "Polak, Czech $i$ Niemiec złowili złota rybkę. Obiecała, że jeśli ja wypuszcza, to spetni po jednym zyczeniu kazdego z nich. Czech poprosit o najlepszy samochód, Niemiec poprosit o lepszy samochód od sasiadów. A Polak prosit o to, zeby sasiadom te samochody się zepsuty» (T);

2. «Co powie amerykański sasiad sasiadowi, który ma piękna krowę? - Masz super krowę! A co powie polski sasiad sasiadowi? - Aby Ci ta krowa zdechta» $(K)$.

Існування у студентській мовній свідомості автостереотипу поляка як недолугого і відсталого засвідчує запропонований торунськими і люблінськими респондентами текст анекдоту: "Dostat Polak 2 kule i zastat zamknięty w pokoju bez drzwi $i$ okien, bez żadnego wyposażenia, zostat poproszony o zrobienie z nimi coś niemożliwego. Jedna zgubit, druga zepsuł» (2) (T, Лб).

Відсталість поляка експонується й у запропонованому студентом 3 Торуня анекдоті: «Diabet zamknat Polaka, Niemca $i$ Ruska $w$ osobnych pokojach na caty rok $i$ kazdy z nich miat otrzymać roczne zapasy tego, czego sobie życza. Za rok Niemiec miat wielkie zapasy piwa, Rusek miat dużo seksu, a Polak lezać na podłodze błagat o zapalniczkę do papierosów» (T).

В одному анекдоті експонується неосвіченість, недолугість і відсталість поляків. Виявлені риси відображають культурний аспект, складовою частиною якого $є$ інтелігентність у широкому розумінні. Наприклад, «Czemu Chrystus nie urodził się $w$ Polsce? - Nikt nie mógt znaleźć 3 mędrców $i$ dziewicy» (2) (Л, Ж). Жорстокість ${ }^{8}$ (7,3\%) поляків у відношенні один до одного, а також відсталість поляка віддзеркалюється в запропонованому студентами 3 Жешова, Торуня, Катовіц анекдоті: «Jak ściagnąć jednorękiego Polaka z drzewa? - Pomachać do niego» (3) (Ж, $T, K)$. Виявлені на основі цього анекдоту риси поляка залічуємо до культурного і комунікаційно-психічного аспектів.

Основою для жартів в одному 3 анекдотів $€$ фонетичні особливості сілезького діалекту польської мови (культурний аспект). У цьому анекдоті віддзеркалюється також нелюбов до осіб, що походять 3-поза Сілезії (комунікаційно-психічний аспект). Цю рису простежуємо

\footnotetext{
8 Жорстокість поляків віддзеркалено в анекдоті, що у відповідях респондентів трапляється 4 рази: "Jak zatrzymać polska kawalerię - Wyłączyć karuzelę” (4) (B, Ж).
}

на основі слова gorol, яке в Сілезії вживають в етноцентричному значенні «гірша людина», яка не проживає в цій місцевості. Наприклад, "Przyjechat Polak na Śląsk. Po jakimś czasie pisze list do domu: - Oni wszystko mówia na G. Zwierzę to Gowiydź, Gybuntag! - A na ciebie jak mówią? - Gorol!» (K). Варто наголосити, що цей гумористичний текст запропоновано респондентом із Катовіц, отже, місце проживання детермінує побутування локальних анекдотів.

В анкетному корпусі анекдотів 6 разів з'явився приклад, що висміює таку автостереотипну рису поляка, як «брудний» $(6,25 \%)$. Ця риса відображає сприйняття поляками самих себе крізь призму фізичного аспекту: «Gdzie schować pieniadze tak, by Polak nie znalazł? - Pod mydtem» (6) (Ж, B).

Серед виявлених анекдотів натрапляємо на політичний, де діалог між президентами Польщі i Росії відображає ставлення поляків до Росії. Так, російський президент висміює економічну ситуацію в Польщі і стверджує про спад ВВП, натомість польський президент передбачає, що Китай захопив Росію: «2100 rok, spotykaja się $w$ zaświatach prezydent Polski i prezydent Rosji, przegladaja obecne informacje ze świata. Prezydent Rosji mówi: Zobacz, w Polsce PKB drastycznie spada. Na to prezydent Polski: "A zobacz to! Zamieszki na granicy polsko-chińskiej» (Лб).

Висновки. Отже, на підставі проведеного аналізу зібраних шляхом анкетування анекдотів виокремлюємо риси і відповідні їм аспекти позамовної дійсності, крізь призму яких польські студенти висміюють представників своєї національності: комунікаційно-психічний, політичний, фізичний, культурний, психосуспільний. Усі зібрані з анкет анекдоти є носіями певних автостереотипних рис. Найчастіше (Додаток 1) польські студенти висміюють риси, що належать до психосуспільного аспекту, де злодійство (30,2\%) поляків переважає над лінивством $(10,41 \%)$, алкоголізмом (8,33\%). У комунікаційно-психічному аспекті позитивні автостереотипні риси поляка домінують над негативними: вміння давати собi раду/знаходити вихід із ситуації $(13,5 \%)$, відважність (8,3\%) частіше експонуються в анекдотах, ніж жорстокість (7,3\%), заздрість (3,1\%). Автостереотипні уявлення студентів про поляка формуються також на основі анекдотів, що віддзеркалюють риси 3 культурного аспекту, наприклад, недолугість/відсталість (13,5\%). Фізичний аспект представлений однією автостереотипною рисою брудний (6,25\%). Простежено, що виявлені риси здебільшого увиразнюються шляхом протиставлення поляка і представників інших національностей, наприклад, класичної тріади поляка, німця, «русека», чи зрідка як третій представник виступає француз, американець або японець. 


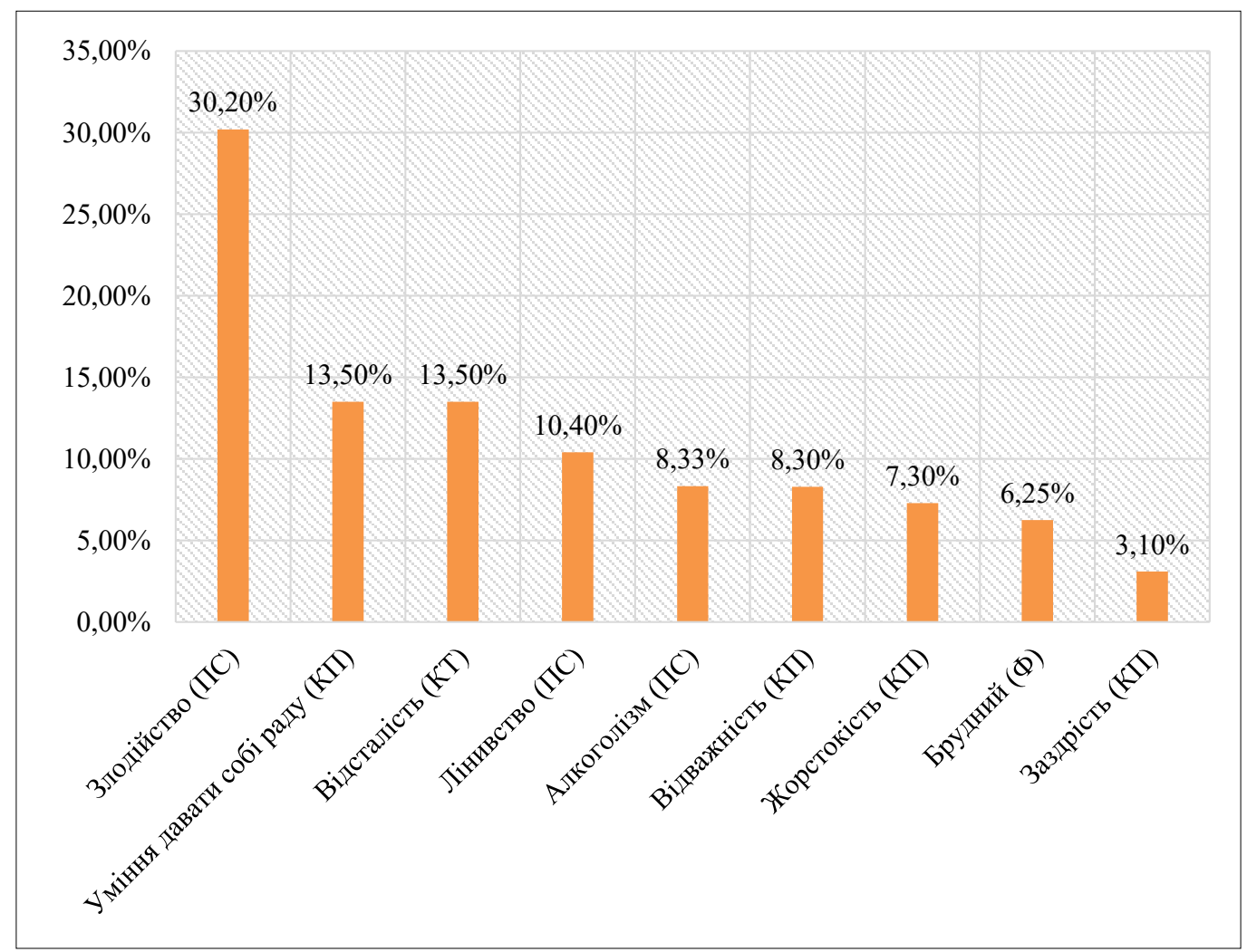

Рис. 1. Автостереотипні риси поляка в анекдотах

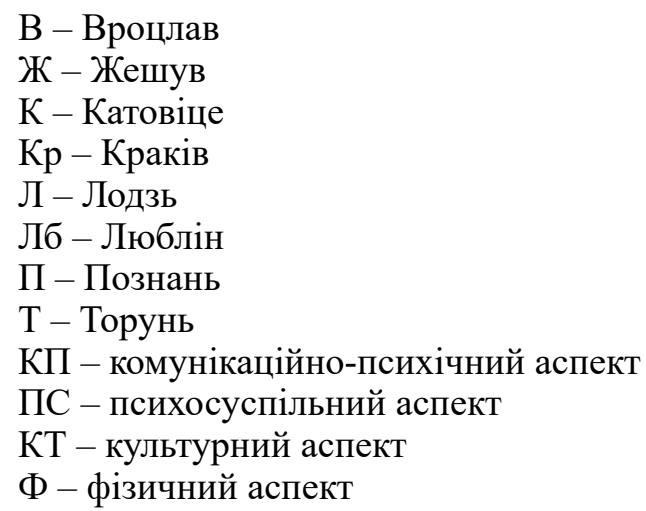

\section{ЛITEPATУРA}

1. Дмитренко М. Види, жанри фольклору. Анекдот. URL: http://ukrlife.org/main/evshan/folklorystyka2. $\mathrm{htm}$ (дата звернення: 05.11.2020).

2. Словник української мови. URL: http://sum.in.ua/s/anekdot (дата звернення: 05.11.2020).

3. Филипець О. Автостереотип поляка і гетеростереотип українця у середовищі торунських студентів. Z bliska i z daleka. Język polski w badaniach językoznawców lwowskich i toruńskich / pod red. M. GębkiWolak, A. Krawczuk. Toruń, 2019. S. 217-234.

4. Филипець О. Етностереотипні уявлення про поляка та українця серед студентів Жешівського університету (крізь призму асоціацій із предметами). Zeszyt Naukowy Prac Ukrainoznawczych. Gorzów, 2019. № 3. S. 155-165.

5. Филипець О. Способи категоризації етноніма поляк у «інтерпретаціях» студентів Сілезького університету. Закарпатські філологічні студії. Ужгород, 2020. № 14 (1). С. $42-48$.

6. Bańsko M. Inny słownik języka polskiego. Warszawa, 2000. T. 2. 
7. Bartmiński J. Ankieta jako pomocnicze narzędzie rekonstrukcji językowego obrazu świata. Wartości $w$ językowym obrazie świata Stowian i ich sasiadów, t. 3. Problemy eksplikowania i profilowania pojęć / pod red. I. Bielińskiej-Gardziel, S. Niebrzegowskiej-Bartmińskiej, J. Szadury. Lublin, 2014. S. 279-308.

8. Bartmiński J. Etnolingwistyka, lingwistyka kulturowa, lingwistyka antropologiczna. Język a kultura / pod. red. A. Dąbrowskiej. Wrocław, 2008. T. 20. S. 15-33.

9. Bartmiński J., Lappo I., Majer-Baranowska U. Stereotyp Rosjanina i jego profilowanie we współczesnej polszczyźnie. Etnolingwistyka. Lublin, 2002. № 14. S. 105-152.

10. Bartmiński J. Punkt widzenia, perspektywa, językowy obraz świata. Językowy obraz świata / pod red. J. Bartmińskiego. Lublin, 1999. S. 103-120.

11. Bartmiński J. Wybrane koncepty w świetle danych ankietowych: Europa, Europejczyk, ojczyzna, Polska, Polak, świat, Wschód, Zachód. Polskie wartości w europejskiej aksjosferze / pod red. S. NiebrzegowskiejBartmińskiej, M. Nowosad- Bakalarczyk, S. Wasiuty. Lublin, 2014. S. 248-308.

12. Brzozowska D. Zmienność i trwałość stereotypów w dowcipach - na przykładzie tekstów o naukowcach. 70 współczesnej polszczyzny. Zjawiska. Procesy. Tendencje / pod red. A. Dunin-Dutkowskiej, A. Małyski. Lublin, 2013. S. 603-614.

13. Buttler D. Polski dowcip językowy. Warszawa, 1968.

14. Jakubiak E. Stereotyp Żyda w dowcipach przełomu XIX/XX wieku. Etnolingwistyka. Lublin, 2003. № 15. S. $128-138$.

15. Kajak P. Polak i inne chłopaki. Dowcipy w nauczaniu kultury polskiej jako obcej. URL: http://kms.polsl.pl/ $\mathrm{prv/spnjo1/referaty/kajak.pdf} \mathrm{(дата} \mathrm{звернення:} \mathrm{22.10.2020).}$

16. Kozinowa A., Potapowa O. Stereotypy językowe w dowcipach rosyjskich. Etnolingwistyka. Lublin, 2002. № 14. S. 69-92.

17. Krawczuk A. Nowe profile ukraińskiego stereotypu Polaka (na podstawie ankietowania studentów lwowskich). Postscriptum Polonistyczne. Katowice, 2008. № 1 (1). S. 147-170.

18. Niebrzegowska-Bartmińska S. Od separacyjnego do holistycznego opisu językowego obrazu świata. Na marginesie dyskusji nad kształtem artykułów w Leksykonie aksjologicznym Słowian i ich sąsiadów. Wartości w językowo-kulturowyn obrazie świata Stowian i ich sąsiadów, t. 3. / pod red. I. BielińskiejGardziel, S. Niebrzegowskiej-Bartmińskiej, J. Szadury. Lublin, 2014. S. 71-102.

19. Skarżyński M. Rosyjskie липа, липовый i polskie lipa, lipny. LingVaria. Kraków, 2015. № 1 (19). S. 195-204.

20. Słownik języka polskiego. URL: https://sjp.pwn.pl/szukaj/dowcip\%20.html (дата звернення: 05.11.2020).

21. Szadura J.Z badań nad autostereotypem Polaka: kryteria polskości. Nazwy wartości: studia leksykalnosemantyczne / pod red. J. Bartmińskiego, M. Mazurkiewicz-Brzozowskiej. Lublin, 1993. S. 239-256.

22. Szczęsna E. Słownik pojęć i tekstów kultury. Warszawa, 2002.

23. Wielki słownik języka polskiego. URL: https://wsjp.pl/do_druku.php?id_hasla=83040\&id_znaczenia= 5206979 (дата звернення: 05.11.2020).

\section{REFERENCES}

1. Dmytrenko M. Vydy, zhanry folkloru. Anekdot. URL: http://ukrlife.org/main/evshan/folklorystyka2.htm (data zvernennya: 05.11.2020).

2. Slovnyk ukrayinskoyi movy. URL: http://sum.in.ua/s/anekdot (data zvernennya: 05.11.2020).

3. Fylypec O. (2019) Avtostereotyp polyaka i geterostereotyp ukrayincya u seredovyshhi torunskyh studentiv. M. Gębka-Wolak, A. Krawczuk (eds). Z bliska $i$ z daleka. Jenzyk polski w badaniach językoznawców lwowskich i toruńskich. Torun. P. 217-234.

4. Fylypec O. (2019) Etnostereotypni uyavlennya pro polyaka ta ukrayincya sered studentiv Zheshivs'kogo universytetu (kriz' pryzmu asociacij iz predmetamy). Zeszyt Naukowy Prac Ukrainoznawczych. Gorzów. Vol. 3. P. $155-165$.

5. Fylypec O. (2020) Sposoby kategoryzaciyi etnonima polyak u «interpretaciyax» studentiv Silezkogo universytetu. Zakarpats'ki filologichni studiyi. Uzhgorod. Vol. 14 (1). P. $42-48$.

6. Bańsko M. Inny słownik języka polskiego. T. 2. / Mirosław Bańsko. Warszawa, 2000.

7. Bartmiński J. (2014) Ankieta jako pomocnicze narzędzie rekonstrukcji językowego obrazu świata. I. Bielińska-Gardziel, S. Niebrzegowska-Bartmińska, J. Szadura (eds). Wartości w językowym obrazie świata Stowian i ich sąsiadów, t. 3. Problemy eksplikowania i profilowania pojęć. Lublin. P. 279-308.

8. Bartmiński J. (2008) Etnolingwistyka, lingwistyka kulturowa, lingwistyka antropologiczna. A. Dąbrowska (eds). Język a kultura Wrocław. T. 20. P. 15-33.

9. Bartmiński J., Lappo I., Majer-Baranowska U. (2002) Stereotyp Rosjanina i jego profilowanie we współczesnej polszczyźnie. Etnolingwistyka. Lublin. Vol. 14. P. 105-152. 
10. Bartmiński J. (1999) Punkt widzenia, perspektywa, językowy obraz świata. J. Bartmiński (eds). Językowy obraz świata. Lublin. P. 103-120.

11. Bartmiński J. (2014) Wybrane koncepty w świetle danych ankietowych: Europa, Europejczyk, ojczyzna, Polska, Polak, świat, Wschód, Zachód. S. Niebrzegowska-Bartmińska, M. Nowosad-Bakalarczyk, S. Wasiuta (eds). Polskie wartości w europejskiej aksjosferze. Lublin. P. 248-308.

12. Brzozowska D. (2013) Zmienność i trwałość stereotypów w dowcipach - na przykładzie tekstów o naukowcach. A. Dunin-Dutkowska, A. Małyska (eds). 70 wspótczesnej polszczyzny. Zjawiska. Procesy. Tendencje. Lublin. P. 603-614.

13. Buttler D. (1968) Polski dowcip językowy. Warszawa.

14. Jakubiak E. (2003) Stereotyp Żyda w dowcipach przełomu XIX/XX wieku. Etnolingwistyka. Lublin. Vol. 15. P. 128-138.

15. Kajak P. Polak i inne chłopaki. Dowcipy w nauczaniu kultury polskiej jako obcej. URL: http://kms.polsl.pl/ prv/spnjo1/referaty/kajak.pdf.

16. Kozinowa A., Potapowa O. (2002) Stereotypy językowe w dowcipach rosyjskich. Etnolingwistyka. Lublin. Vol. 14. P. 69-92.

17. Krawczuk A. (2008) Nowe profile ukraińskiego stereotypu Polaka (na podstawie ankietowania studentów lwowskich). Postscriptum Polonistyczne. Katowice. Vol. 1 (1). P. 147-170.

18. Niebrzegowska-Bartmińska S. (2014) Od separacyjnego do holistycznego opisu językowego obrazu świata. Na marginesie dyskusji nad kształtem artykułów w Leksykonie aksjologicznym Słowian i ich sąsiadów. I. Bielińska-Gardziel, S. Niebrzegowska- Bartmińska, J. Szadura (eds). Wartości w językowokulturowyn obrazie świata Stowian i ich sqsiadów, t. 3. Lublin. P. 71-102.

19. Skarżyński M. Rosyjskie липа, липовый i polskie lipa, lipny. LingVaria. Kraków, 2015. nr 1 (19). S. 195-204.

20. Słownik języka polskiego. URL: https://sjp.pwn.pl/szukaj/dowcip\%20.html.

21. Szadura, J. (1993) Z badań nad autostereotypem Polaka: kryteria polskości. J. Bartmiński, M. MazurkiewiczBrzozowska (eds). Nazwy wartości: studia leksykalno-semantyczne. Lublin. P. 239-256.

22. Szczęsna E. (2002). Słownik pojęć i tekstów kultury. Warszawa.

23. Wielki słownik języka polskiego. URL: https://wsjp.pl/do_druku.php?id_hasla=83040\&id_znaczenia= 5206979. 